\title{
VPLIV GEOGRAFSKEGA KURIKULUMA NA KOMPETENCE UČITELJA GEOGRAFIJE
}

\author{
Tatjana Resnik Planinc', Saša Kosten Zabret² \\ Oddelek za geografijo Filozofske fakultete Univerze v Ljubljani, Aškerčeva cesta 2, \\ SI - I000 Ljubljana, Slovenija \\ e-mail': tatjana.resnik-planinc@guest.arnes.si \\ e-mail2: sasa.kosten-zabret@guest.arnes.si
}

Izvirni znanstveni članek

COBISS 1.01

\section{Izvleček}

Prispevek obravnava vpliv geografskega kurikuluma na kompetence učitelja geografije. V tem okviru namenja posebno pozornost tako pridobivanju kompetenc učitelja geografije kot samemu pomenu teh kompetenc za geografsko izobraževanje, pri čemer je jasno razviden kompleksen in simbiotičen odnos med kurikulumom in kompetencami. Kompetence bi morale zato izhajati iz teorij, ki se nanašajo na vrednote, znanje, kurikulum in celoten izobraževalni proces, ki podpira dobro pedagoško prakso.

Ključne besede: geograf, geografija, kurikulum, učitelj, študent, študij

\section{INFLUENCE OF THE GEOGRAPHICAL CURRICULUM ON COMPETENCES OF GEOGRAPHY TEACHERS}

\begin{abstract}
The paper analyses the influence of geographical curriculum on competences of geography teacher. It is focused on complex and symbiotic relation between curriculum and achieved and recommended competences of geography teacher and their importance for geographical education. The competences should therefore be derived from the theories, concerning values, knowledge, curriculum and whole educational process, which underpin good pedagogical practice.
\end{abstract}

Key words: geographer, geography, curriculum, teacher, student, study. 


\section{OPREDELITEV POJMOV}

Evolucija šolskih kurikulumov in narava njihovega razvoja nudita ozadje za nadaljnje razprave o položaju geografije $\mathrm{v}$ kurikulumih, načinih našega doprinosa $\mathrm{v}$ razpravah $\mathrm{o}$ kurikularnem razvoju ter ustrezne strategije za zagotavljanje uspešnega in učinkovitega poučevanja in učenja geografije v razredu (Chalmers 2007, 3). Razumevanje razvoja geografskega kurikuluma je pogojeno z določenim modelom kurikularnega procesa. Čeprav je bil v preteklosti Tylerjev model (1949) korak naprej, pa je bila njegova slabost linearnost modela, ki je povezoval cilje, vsebine, metode in evalvacijo kurikularnega proces (Slika 1), ne da bi pri tem nakazoval mehanizem delovanja povratne informacije.

Slika 1: Tylerjev linearni model kurikularnega procesa (cv: Graves 1996, 73).

Figure 1: Tyler's linear model of the curriculum process (cv: Graves 1996, 73).

$$
\text { ? >>> cilji >>> vsebine }>>>\text { metode }>>>\text { evalvacija }>\text { >> ? }
$$

Nasprotno pa je Wheeler trdil, da je krožni model, v katerem mehanizem povratne informacije vpliva na spremembe ciljev, bolj usklajen z dinamiko kurikularnega procesa.

Slika 2: Wheelerjev krožni model kurikularnega procesa (cv: Graves 1996, 73).

Figure 2: Wheeler's circular model of the curriculum process (cv: Graves 1996, 73).

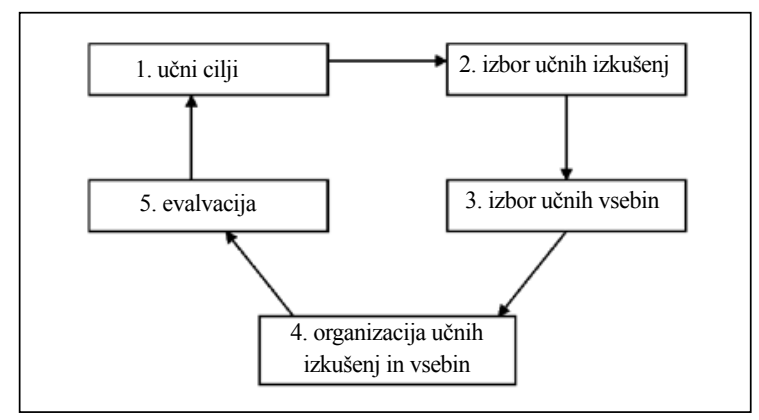

Vendar se je tako $\mathrm{v}$ preteklosti kot $\mathrm{v}$ sedanjosti navidezna preprostost ideje pogosto izkazala za težko izvedljivo v praksi. Po Kerru (1968) se je najprej potrebno odločiti o tem, kdo oz. kaj bo formuliralo same učne cilje: bo to družba, znanstvena veda ali celo učenci sami? Kateri vidik učnih ciljev bi morali poudariti - kognitivne, afektivne, psihomotorične ali manualne veščine (Kerr 1968, cv: Graves 1996, 73 - 74)? Tudi 40 let pozneje ta vprašanja še vedno ostajajo aktualna.

Kurikularni proces ni preprost krožni sistem, ki se giba od ciljev do evalvacije k novim ciljem, ampak interaktiven sistem, znotraj katerega vsak del vpliva na drugega. Graves (1996) trdi, da morda sploh ne obstaja ena sama izhodiščna točka, kot so na primer učni cilji, temveč lahko učitelj začne proces na katerikoli točki sistema.

Kot vsebino razume Graves koncepte, principe, teorije in veščine in ne dejstev, ki 
bi nudila kontekst, znotraj katerega naj bi se poučevala določena vsebina. Ko govorimo o sodobnem kontekstu, se moramo zavedati, da se le ta razlikuje od države do države, tako kot so različni njihovi politični, ekonomski in družbeni vplivi. Postavlja se vprašanje, ali smo v celostnem razumevanju kurikularnega procesa dejansko naredili izrazite premike $\mathrm{v}$ njegovem razumevanju. Res je, da se veliko bolj zavedamo pomena kurikularnega procesa $\mathrm{v}$ kontekstu posameznih šolskih predmetov in da znotraj njih prepoznavamo ideje in veščine, ki bi jih bilo smiselno vključiti v izobraževanje na določeni stopnji šolanja. Obenem vemo, da kurikularni razvoj ni mogoč brez učiteljevega razvoja. Kurikularni razvoj ne more uspeti brez občutnega vložka v strokovno izobraževanje učiteljev. Zgodi se, da so naša pričakovanja do učiteljev nerealna in tako nekonstruktivna. Zato je vitalnega pomena, da zagotovimo povratno informacijo razvijalcem kurikuluma, pri čemer nimamo v mislih samo posvetovanja z učitelji, temveč domišljeno evalvacijo kurikularnega procesa, ki bo vključevala tudi učenčevo videnje kurikularnega razvoja.

Slika 3: Gravesov model za kurikularno načrtovanje v geografiji. (Graves 1996, 75)

Figure 3: Graves'model for curriculum planning in geography.. (Graves 1996, 75)

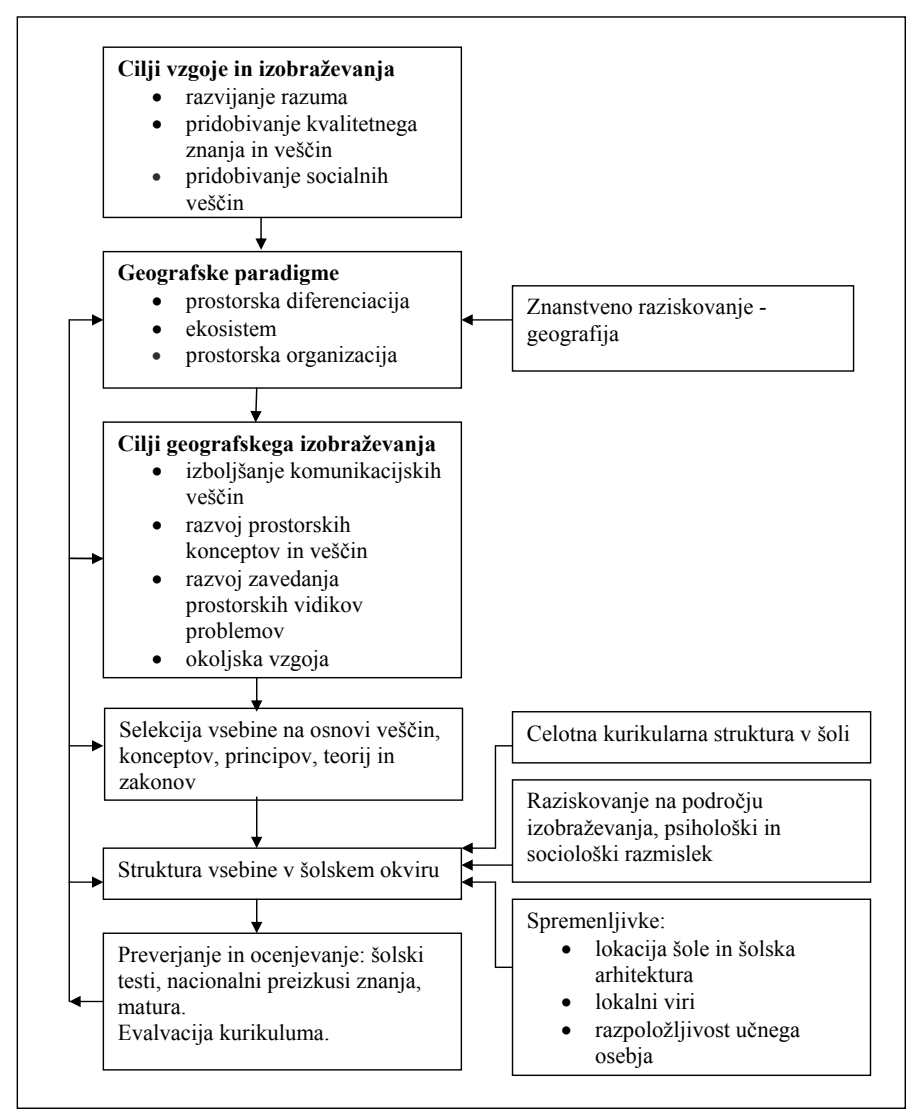


Po Chalmersovem mnenju (2007) prevladuje v izobraževalnih ustanovah prepričanje, da kurikulum na racionalen način zapisuje oz. narekuje zaporedje postopkov in njihovih vsebin. Krovni namen kurikulov je sistematizacija učenja z namenom zagotavljanja uravnoteženega in kohezivnega učnega programa, ki naj bi temeljil na pričakovanih učnih dosežkih. Istočasno vodijo kurikulumi v koordiniran razvoj poučevanja in učil skupaj z razvojem izobraževalnih programov za bodoče učitelje (Chalmers 2007, 4). Povsem razumljivo je, zakaj so tako javni mediji kot znanstvena literatura, ki se ukvarja z raziskovanjem izobraževanja, polni razprav o šolskih kurikulumih. Ker je z njihovim oblikovanjem, izvedbo in sprejemanjem s strani države predlaganih oziroma zapovedanih izkušenj v razredu povezano veliko število ljudi, je zanimanje in odziv strokovne in laične javnosti logična posledica obstoječega stanja.

Skozi desetletja se je razvoj geografske stroke zrcalil tudi v geografskih kurikulumih za različne stopnje šol. Vendar ni mogoče spregledati dejstva, da so bili le ti vedno nekaj korakov za razvojem in dognanji tako geografske kot drugih pedagoško - psiholoških strok. Čeprav zgleda morda na prvi pogled priprava kurikuluma dokaj enostaven proces, pa temu še zdaleč ni tako.

Skladno s spremenjenim pojmovanjem znanosti in znanja se spreminja tudi razumevanje profesionalne kompetentnosti strokovnjakov na posameznih področjih dejavnosti. Pojem profesionalne kompetentnosti je pogosto definiran kot sposobnost opravljanja zadane naloge $\mathrm{v}$ skladu z določenimi standardi. Slovar slovenskega knjižnega jezika (SSKJ 1985, 388) definira kompetenco kot obseg oz. mero odločanja, pristojnost ali pooblastilo, za »kompetentnega« pa velja tisti, ki je »pristojen, pooblaščen; kdor temeljito pozna, obvlada določeno področje; usposobljen, poklican«.Kompetentnostpajelastnostoz.značilnostkompetentnega.Pregled tujih slovarjev pokaže pomensko nejasnost in večplastnost slovarskih definicij pojma kompetentnosti. Tudi znanstvena in strokovna literatura s širšega področja izobraževanja in profesionalnega razvoja ne podaja enoplastnega oz. enoznačnega razumevanja pojma kompetentnosti (Cvetek 2004). Tako je npr. Jarvis (Jarvis 1983, cv: Cvetek 2004, 148) prepričan, da je mogoče govoriti o kompetentnosti pri opravljanju nekega poklica le, če ta obsega vse vidike učinkovitosti oziroma, da za dobro prakso stoji dobra teorija. Profesionalna kompetentnost po Jarvisovem mnenju sestoji iz strokovnega znanja, didaktičnega in psihološkega znanja oziroma veščin ter profesionalnih stališč.

Nekoliko drugačen pristop k pojmovanju kompetentnosti ima Wallace (Wallace 1991, cv: Cvetek 2004, 148), ki meni, da lahko izraz profesionalna kompetentnost uporabljamo z dveh vidikov, od katerih je prvi statičen, drugi pa dinamičen. V prvem, imenuje ga začetna kompetentnost, gre za bolj ali manj formalno dokazilo, da nekdo izpolnjuje določene minimalne zahteve svojega poklica. V skladu z drugim vidikom pa kompetentnost ne pomeni več zgolj zadostnosti, temveč vrhunsko strokovno usposobljenost, pri čemer je pot, ki do nje vodi, vsaj tako, če ne še bolj pomembna kot sam cilj.

Na podoben način, torej skozi povezovanje kompetentnosti s profesionalno potjo(kariero) učiteljev, razmišlja Pollard (Pollard 1997, cv: Cvetek 2004, 148), ki razlikuje med tremi nivoji kompetentnosti in sicer nivojem učitelja začetnika, nivojem kompetentnega učitelja in nivojem učitelja eksperta. Te tri nivoje avtor povezuje s štirimi sposobnostmi razumevanja in odločanja v konkretni situaciji: sposobnostjo prepoznavanja stvari, sposobnostjo razlikovanja pomembnih stvari, sposobnostjo razumevanja celotne situacije in sposobnostjo sprejemanja odločitev (Pollard 1997, cv: Cvetek 2004, 148 - 149). 


\section{I.I Novi profesionalizem}

Pojem »razmišljajočega praktika« je definiral Schon (Schon 1983, cv: Razdevšek Pučko 2004, 56) in s tem legitimiziral poučevanje kot intelektualno aktivnost, kjer učitelji analizirajo svoje izkušnje in na tej podlagi tudi konstruirajo nova spoznanja.

Oblike, s katerimi učitelj pri svojem delu razvija posamezne kompetence, omogočajo pristop »od znotraj«, poleg tega pa presegajo meje izkušenj znotraj štirih zidov učilnice, omogočajo refleksijo, profesionalen dialog z drugimi, ustvarjajo se podporne skupine/dvojice, ustvarja se profesionalna kultura, ki omogoča oblikovanje intelektualnega okolja učiteljev ter izmenjavo izkušenj.

Obenem se od učiteljev še vedno pričakuje dobro didaktično in metodično znanje, organizacijske spretnosti, psihološka znanja ter razvijanje učnih strategij. V učnih načrtih je še vedno premalo poudarka na timskemu delu in sodelovanju različnih učiteljev, hkrati pa $\mathrm{v}$ njih ni zaslediti nujnosti razvijanja lastne profesionalnosti učiteljev v procesu vseživljenjskega učenja (Resnik Planinc, Kosten Zabret 2006).

\section{KOMPETENCE PROFESIONALNO USPOSOBLJENEGA UČITELJA}

Iz zgornjega pregleda pojmovanj kompetentnosti je razvidno, da gre za kompleksen pojem, ki presega okvir posameznih strok in področij dejavnosti, kar velja tudi za poučevanje in pedagoški poklic. Dejstvo pa je, da postajajo kompetence v sodobnem svetu sestavni del kriterijev za ocenjevanje dela učiteljev (in seveda tudi drugih profesionalcev) ter posledično tudi za njihovo izobraževanje in usposabljanje.

\section{I Nove vloge učiteljev}

Zaradi sprememb v družbi morajo učitelji posledično sprejeti nekatere nove vloge, nekatere prejšnje pa spremeniti ali opustiti. Pri tem je ključnega pomena pripravljenost za spreminjanje in prilagajanje tradicionalnih vlog novim okoliščinam (mentorska vloga, organizacija učnih situacij, intenzivnejše vključevanje učencev) ter sprejemanje nekaterih novih vlog (vključevanje novih tehnologij v pouk). Obenem so učitelji soočeni z vse večjim številom učno in vedenjsko težavnih učencev, ki zahtevajo drugačne načine poučevanja, ter $\mathrm{z}$ vse pogostejšimi zunanjimi oblikami preverjanja znanja. Dejstvo je, da med študijem pridobljene kvalifikacije učitelju ne zadoččajo več. Učitelj je soočen z nujnostjo sodelovanja $\mathrm{z}$ drugimi učitelji, strokovnimi delavci in starši, pri čemer mora biti usposobljen za refleksijo, raziskovanje in evalvacijo lastnega dela. Za uspešno prevzemanje vseh teh novih vlog mora biti učitelj odprt za spremembe in motiviran za vseživljenjsko učenje in stalni profesionalni razvoj (Resnik Planinc, Kosten Zabret 2006). 


\section{KOMPETENCE UČITELJA GEOGRAFIJE}

Geografsko izobraževanje se danes, morda še izraziteje kot v preteklosti, sooča z velikimi spremembami. Poleg strokovnih geografskih vsebin se mora bodoči učitelj geografije v sklopu profesionalno usmerjenega študija, ki bo efektivno povezoval teorijo in prakso ter omogočal dostop do učiteljskega poklica, seznaniti tudi s sociološkimi, psihološkimi, političnimi in kulturnimi vidiki učenja in poučevanja geografije.

Praktične izkušnje lahko izhajajo le iz tesnega sodelovanja s šolami. Študij mora zato slediti potrebam bodočih učiteljev geografije ter ponuditi stimulativen program akademskega študija v prepletu s praktično poklicno izkušnjo.

Študent mora imeti možnost razvijati svoje lastno znanje, spretnosti in zaupanje predvsem $\mathrm{z}$ vidika zaposlitve $\mathrm{v}$ poklicih, povezanih $\mathrm{z}$ geografskim izobraževanjem. Narava, namen in vsebine geografskega izobraževanja, s poudarkom na nepristranosti, vseživljenjskem učenju, mednarodno primerljivem izobraževanju ter na delu temelječem učenju, so izrednega pomena, saj se morajo odzivati na hitro se spreminjajoč svet novih možnosti za učenje skozi življenje in kariero.

Na fakulteti se študenti seznanijo z vsebinami o geografskem izobraževanju kot so poučevanje in učenje, geografski kurikulum, razvijajo komunikacijske veščine in veščine kritičnega mišljenja, razvijajo sposobnost ravnanja $z$ informacijami in njihovega podajanja ter se seznanjajo z različnimi vidiki in segmenti pouka. Med pedagoško prakso ali pripravništvom bi moralo biti njihovo delo praktično, v skladu s šolskim okoljem in osredotočeno na »učečega se«, tako da bi študentje pridobili veščine in znanje, potrebne za zaposlitev, osebno rast in načrtovanje kariere. Olajšati bi jim morali pridobivanje znanja, veščin in vrednot, spodbujati samorefleksiven pristop k poklicni aktivnosti in položiti temelje za nadaljnji profesionalni razvoj (Resnik Planinc, Kosten Zabret 2006).

\section{ANALIZA IN VREDNOTENJE KOMPETENC UČITELJA GEOGRAFIJE Z VIDIKA BODOČIH UČITELJEV TER Z VIDIKA IZKUŠENIH UČITELJEV PRAKTIKOV}

\section{I Namen empirične raziskave in hipoteze}

Izobraževanje bodočih učiteljev geografije je zahteven proces izoblikovanja mladega človeka, ki naj bi bil v skladu z želenimi kompetencami kos zahtevam poklica, katerega bo $\mathrm{v}$ bližnji prihodnosti predvidoma opravljal. Zato je bil namen raziskave med študenti in absolventi dvopredmetne pedagoške smeri geografije ugotoviti, $v$ kolikšni meri jih je študij opremil s kompetencami, ki jih od njih pričakujejo tako geografska stroka kot ostale, z izobraževanjem povezane stroke. $\mathrm{V}$ težnji $\mathrm{k}$ izboljšanju in nadgradnji obstoječega stanja na področju izobraževanja bodočih učiteljev, tako geografije kot drugih predmetov, je seveda smiselno in nujno preverjanje obstoječega stanja ter vrednotenje nivoja doseženih ciljev. V nadaljevanju smo izvedli enako raziskavo tudi med izkušenimi učitelji praktiki, predvsem z namenom ugotoviti morebitna ujemanja in razhajanja, izhajajoča iz izkušenj praktikov na eni strani ter izhodiščnim položajem bodočih diplomantov, katerih vedenje na tej stopnji temelji v 
največji meri na teoretičnem poznavanju in vedenju o obravnavani problematiki. $Z$ raziskavo smo želeli ugotoviti, če:

1. Študenti v času študija pridobijo ustrezne kompetence za opravljanje učiteljskega poklica;

2. se študenti zavedajo pomena kompetenc $\mathrm{v}$ povezavi s kvalitetnim opravljanjem učiteljskega poklica;

3. so študenti $\mathrm{v}$ času študija razvili sposobnost kvalitativnega vrednotenja poklicnih in osebnih kvalitet učitelja,

4. obstaja med današnjimi študenti in učitelji praktiki razlika $v$ deležu med študijem pridobljenih kompetenc opravljanje učiteljskega poklica;

5. se učitelji praktiki zavedajo pomena kompetenc $\mathrm{v}$ povezavi s kvalitetnim opravljanem učiteljskega poklica.

\subsection{Metodologija dela}

\subsubsection{Metode dela:}

1. deskriptivna metoda

2. kavzalno - neeksperimentalna metoda

3. kvantitativna metoda

\subsubsection{Tehnike:}

1. anketa

2. kvantitativna analiza rezultatov anket

\subsubsection{Instrumenti:}

1. anketni vprašalniki za študente

2. statistični izračuni

\subsubsection{Raziskovalni vzorec}

Raziskava je izvedena na namenskem (glede na izkušnje $\mathrm{v}$ procesu izobraževanja za poklic učitelja geografije) vzorcu 38 študentov, ki so bodisi ravnokar zaključili 4. letnik študija ali pa so že absolventi, ter na namenskem vzorcu 17 učiteljev geografije.

\subsubsection{Postopek zbiranja podatkov}

Podatki so bili zbrani z anketiranjem. Po sondažni uporabi anketnega vprašalnika je sledilo njegovo vsebinsko - metodološko urejanje. Vprašalnik je bil strukturiran iz dveh sklopov vprašanj. Prvi sklop vprašanj so sestavljala vprašanja v obliki trditev, ki so jih anketiranci vrednotili s pomočjo štiri-stopenjske in tri-stopenjske ocenjevalne lestvice, drugi sklop pa vprašanja odprtega tipa.

V nadaljevanju bomo predstavili le tisti del rezultatov raziskave, ki so pomembni z vidika vpliva geografskega kurikuluma na kompetence učitelja geografije.

Sklop vprašanj, ki jih interpretiramo v nadaljevanju, je kot osnovo zajel vse kompetence učitelja začetnika, ki smo jih delno povzeli po Cvetku (Cvetek 2004, 150 - 152), delno pa nadgradili $\mathrm{z}$ lastnimi formulacijami. Vsako posamezno kompetenco so morali anketiranci ovrednotiti z dveh vidikov:

1. v kolikšni meri so posamezno kompetenco pridobili v času študija $(1=$ nisem je pridobil/ a, 2 = pridobil/a sem jo $\mathrm{v}$ zadostni meri, 3 = pridobil/a sem jo ustrezni meri, $4=$ pridobil/ a sem jo v celoti) 
2. označiti smiselnost in pomen posamezne kompetence $(1=$ nepomembna, $2=$ pomembna, $3=$ zelo pomembna)

\subsubsection{Postopek obdelave podatkov}

Zapisane odgovore študentov in učiteljev praktikov smo statistično obdelali na deskriptivnem nivoju. Vprašanja odprtega tipa smo ustrezno kategorizirali.

\subsection{Rezultati in interpretacija}

Čeprav smo v raziskavi podrobno razčlenili in vrednotili posamezne skupine kompetenc, na tem mestu podajamo le ključne ugotovitve. $\mathrm{V}$ nadaljevanju so podatki prikazani kot povprečne vrednosti (ocene) za vsako posamezno postavko, vendar sta stolpca »pridobljeno; pomembno« med sabo zaradi različnega izhodišča primerljiva le z vidika odstotnih deležev. Rezultati odgovorov, ki se nanašajo na pridobljene kompetence učitelja začetnika v času študija ter na celostno vrednotenje kompetenc $\mathrm{z}$ vidika študentov in učiteljev, so podani $\mathrm{v}$ tabelaričnem zapisu (Preglednica 1) in razdeljeni na štiri sklope:



Preglednica 1: Vrednotenje kompetenc učitelja geografije z vidika bodočih učiteljev ter učiteljev praktikov.

Table 1: Geography students' and geography teachers' evaluation of the groups of competences.

\begin{tabular}{|c|c|c|c|c|c|}
\hline & & ŠTU & NTI & UČl & \\
\hline KOMPI & ENCA & Pridobljeno & Pomembno & Pridobljeno & Pomembno \\
\hline 1. & Predmet in vsebine & 2,71 & 2,78 & 2,25 & 2,81 \\
\hline & poučevanja & $677^{\prime} \%$ & $92 ' 7 \%$ & $56 ' 2 \%$ & $93{ }^{\prime} 7 \%$ \\
\hline 2 & Dolox razrody & 2,42 & 2,71 & 1,94 & 2,71 \\
\hline & Deto v Taztedu & $60 ' 5 \%$ & $903 \%$ & $48 ' 5 \%$ & $90 ’ 3 \%$ \\
\hline & Vollo.. & 2,65 & 2,88 & 2,06 & 2,88 \\
\hline & Komunikacija & $66 ' 2 \%$ & $96 \%$ & $51 ' 5 \%$ & $96 \%$ \\
\hline & Mot dit & 2,49 & 2,57 & 1,95 & 2,56 \\
\hline & VICtudina & $62 ' 2 \%$ & $85 ' 7 \%$ & $48^{\prime} 7 \%$ & $85 ' 3 \%$ \\
\hline & Vodonia & 2,29 & 2,66 & 1,86 & 2,67 \\
\hline & vocicije & $57 \cdot 2 \%$ & $88^{\prime} 7 \%$ & $46 ' 5 \%$ & $89 \%$ \\
\hline & - Preverjanje in & 2,27 & 2,76 & 1,90 & 2,72 \\
\hline & ocenjevanje znanja & $56 ' 7 \%$ & $92 \%$ & $47^{\prime} 5 \%$ & $90 ’ 7 \%$ \\
\hline 2 & Doñ & 2,02 & 2,54 & 1,50 & 2,37 \\
\hline & Delovanje sole & $50 ' 5 \%$ & $84 ' 7 \%$ & $37 ' 5 \%$ & $79 \%$ \\
\hline 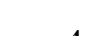 & 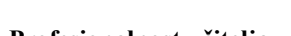 & 2,07 & 2,70 & 1,59 & 2,29 \\
\hline & Proresionamost uciteija & $51 ' 7 \%$ & $90 \%$ & $39^{\prime} 7 \%$ & $76 ' 3 \%$ \\
\hline
\end{tabular}


V sklopu kompetenc, ki se nanašajo na predmet in vsebine poučevanja, so anketiranci le-te pridobili v zadovoljivi meri (67'7 \% študenti, 56'2\% učitelji). Obenem tem kompetencam pripisujejo velik pomen, saj jih je v povprečju kar $77 \%$ študentov in 81 '2 \% učiteljev ovrednotilo kot zelo pomembne. Študentje so največ pridobili na področju izbora ustreznih učil in učnih pripomočkov, največji pomen pa pripisujejo predstavljanju vsebine tega, kar se poučuje, na učencem primeren način. Učitelji so v času študija največ pridobili na področju izkazovanja strokovnega geografskega znanja, ki dosega in presega trenutne zahteve šolskega kurikuluma, medtem ko, tako kot študenti, pripisujejo največji pomen predstavljanju vsebine tega, kar se poučuje, na učencem primeren način.

Slika 4: Primerjava vrednotenja pridobljenih kompetenc učitelja geografije z vidika bodočih učiteljev ter učiteljev praktikov.

Figure 4: Comparison of geography students' and geography teachers'evaluation of the achieved competences.

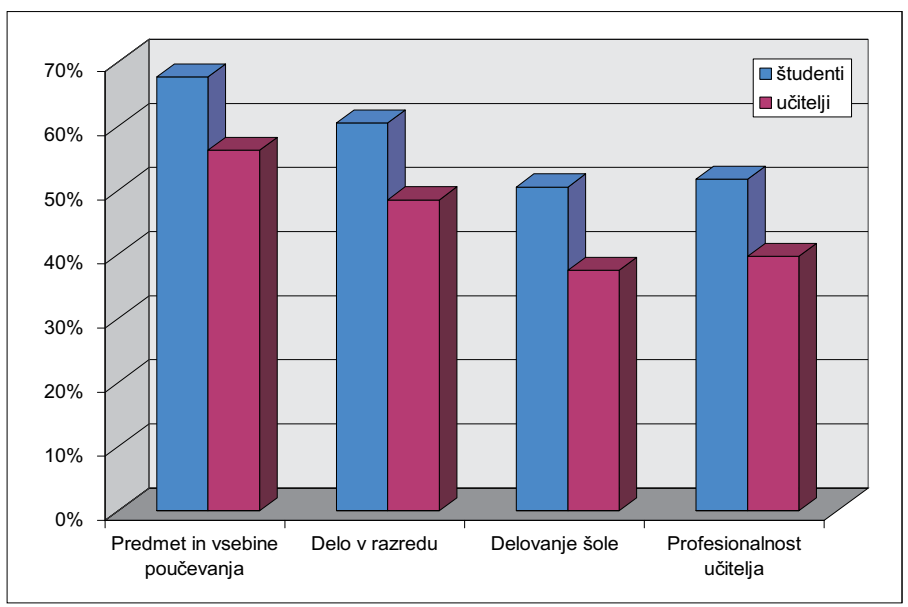

Na področju dela v razredu so študenti v času študija pridobili skupno 60'5 \% kompetenc, učitelji pa le 48'5 \%. Študenti so največ pridobili na področju komunikacije (66’2 \%), najmanj pa na področju preverjanja in ocenjevanja znanja (56'7\%). Učitelji so največ pridobili na področju komunikacije (51'5 \%), najmanj pa na področju vodenja (46'5 \%). Tako študenti kot učitelji pripisujejo pri delu v razredu največji pomen komunikaciji (oboji 96 \%).

$\mathrm{Na}$ področju komunikacije se študenti počutijo najbolj suverene pri podajanju snovi $\mathrm{v}$ jasnem jeziku in na način, ki spodbuja delo učencev, čemur tudi pripisujejo največji pomen. Pri metodiki so največ pridobili na področju izbire in premišljenega načina uporabe najrazličnejših sredstev, vključno z IKT, medtem ko vidijo največji pomen v spodbujanju učencev k prevzemanju pobud in odgovornosti za svoje učenje. Pri vodenju so največ dosegli na področju ohranjanja zanimanja in motivacije učencev. V negativni smeri pa izstopa nizka stopnja pridobljenega znanja in spretnosti na področju obvladovanja vedenja učencev, kjer 29 $\%$ študentov, trdi, da kompetence ni pridobilo oz. da so jo pridobili le v zadostni meri (50\%). Na 
področju preverjanja in ocenjevanja znanja so deleži pridobljenih kompetenc v celoti nekoliko nižji, čeprav posameznim kompetencam pripisujejo zelo velik pomen. $Z$ vidika pridobljenega v pozitivni smeri izstopa razumevanje principov in poznavanje različnih načinov preverjanja in ocenjevanja - torej zgolj teoretični nivo. Učitelji so med vsemi kompetencami, ki se navezujejo na delo v razredu, daleč najmanj (le 33'7 \%) pridobili na področju ugotavljanja in ustreznega odziva na učence, ki imajo posebne izobraževalne potrebe ali učne težave, medtem ko pripisujejo največji pomen ohranjanju zanimanja in motivaciji učencev (delež pomena $100 \%$ ).

Študenti so na področju delovanja šole pridobili le 50'5 \% kompetenc, ki pa jim po drugi strani pripisujejo velik pomen ( 84 '7 \%), medtem ko so učitelji pridobili še manjši delež (37'5 \%) kompetenc, pripisujejo pa jim nižji pomen kot študenti (79 \%). Med študenti je najvišji delež med pridobljenimi doseglo poznavanje virov strokovne pomoči in znanja na šoli ter njihova uporaba. Najmanj so seznanjeni z načini komunikacije s pripadniki drugih poklicev, ki skrbijo za blagostanje otrok, ki obiskujejo šolo, in s pripadniki skupnosti, ki ji služi šola, kot tudi s kolegi na šoli in v povezanih šolah.

Tudi na področju profesionalnosti je delež $\left(51^{\prime} 7 \%\right)$ pridobljenih kompetenc med študenti dokaj nizek, pri čemer pa jim z 90 \% deležem pripisujejo zelo velik pomen. Učitelji so na tem področju v času študija pridobili le $39^{\prime} 7$ \% kompetenc, vendar pa jim pripisujejo manjši pomen $(76 ’ 3 \%)$.

Slika 5: Primerjava vrednotenja pomena kompetenc učitelja geografije z vidika bodočih učiteljev ter učiteljev praktikov.

Figure 5: Comparison of geography students'and geography teachers'evaluation of the importance of the groups of competences.

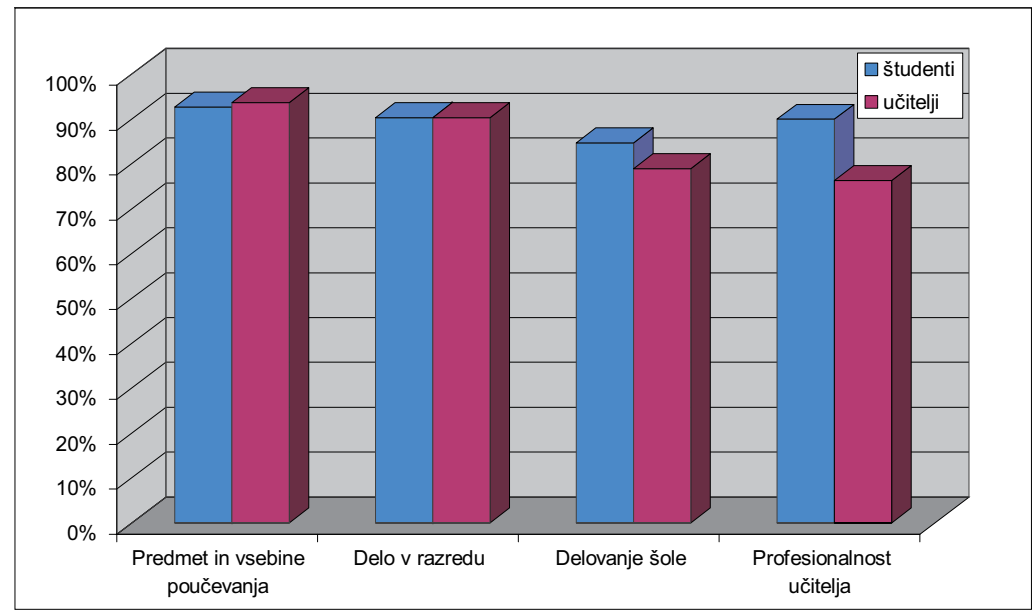

Glede na trenutno stanje lahko kot zadovoljiv ocenimo odgovor anketiranih študentov na vprašanje, v kolikšni meri jih je študij na Filozofski fakulteti usposobil za poklic učitelja. Kar 71'1 \% anketirancev trdi, da jih je študij za delo učitelja usposobil v ustrezni meri, 23’7 \% 
študentov pravi, da jih je usposobil v zadostni oz. zadovoljivi meri, le 2'6 \% pa jih trdi, da jih bodisi ni usposobil bodisi jih je odlično usposobil. Večina jih je tako prepričana, da so dobili osnovo za poučevanje, pri čemer pa poudarjajo, da jim manjka nadgradnja vsebin o šolski zakonodaji, sistemu ter administrativnem delu na šoli. Učitelje o tem nismo izpraševali, ker smo predvidevali, da bodo glede na različne poti in različen čas študija njihovi odgovori težko primerljivi.

Ocenjujemo, da so rezultati raziskave podali realen prerez obstoječega stanja in odgovore na raziskovalna vprašanja. Tako študentje $v$ času študija pridobijo ustrezne kompetence za opravljanje učiteljskega poklica, vendar še ne v zadostni meri, kajti stremeti bi morali k čim večjemu deležu v celoti pridobljenih kompetenc. V celoti pa so se potrdila naša predvidevanja, da se študentje zavedajo pomena kompetenc $\mathrm{v}$ povezavi s kvalitetnim opravljanem učiteljskega poklica, kot tudi predvidevanja, da so v času študija razvili sposobnosti kvalitativnega vrednotenja dela mentorjev ter poklicnih in osebnih kvalitet učitelja. Rezultati raziskave potrjujejo obstoj razlike v deležu med študijem pridobljenih kompetenc za opravljanje učiteljskega poklica med sedanjimi študenti in učitelji praktiki. Obenem pa se učitelji praktiki tako kot študenti zavedajo pomena kompetenc v povezavi s kvalitetnim opravljanem učiteljskega poklica. Zanimivo pa je, da rezultati raziskave govorijo $\mathrm{v}$ prid trditvi, ki smo jo zapisali v podpoglavju Novi profesionalizem, kjer trdimo, da je v učnih načrtih še vedno premalo poudarka na timskemu delu in sodelovanju različnih učiteljev, hkrati pa v njih ni zaslediti nujnosti razvijanja lastne profesionalnosti učiteljev v procesu vseživljenjskega učenja.

\section{SOODVISNOST GEOGRAFSKEGA KURIKULUMA IN KOMPETENC UČITELJEV GEOGRAFIJE}

Ko govorimo o soodvisnosti kurikuluma in kompetenc učiteljev, ne moremo mimo vprašanja odnosa med teorijo in prakso. Problem povezovanja se pojavlja na vmesnih področjih med teorijo in prakso, ki nastanejo pri prehodu od teoretičnega razmišljanja, kaj in kako se učiti in poučevati, na praktično delovanje. Na eni strani obstaja metateoretična pozicija kot posledica interesa, ki velja v teoretični konsistentni refleksiji v širših družbenih, pedagoških in filozofskih povezavah, na drugi strani pa se soočimo s potrebo po stalnem delovanju, odločanju in interakciji. Ta dihotomija med teorijo in prakso, med refleksijo in udejanjanjem je brez dvoma težko obvladljiva. Zato obstaja nevarnost diskontinuitete med tvorjenjem teorije in relevantnostjo prakse. Še posebej se to lahko zgodi takrat, ko dosežeta didaktični proces posredovanja in institucionalizacija tako visoko stopnjo osamosvojitve, da se zdijo njuni vzgibi povezovanja le še sekundarnega pomena. Posledično izginjajo procesi posredovanja teorije v prakso, saj ne doživljajo tematiziranja. Tako nastane prepad med teorijo in prakso (Kosevski Puljić 2006, 158).

Profesionalna učiteljska znanja danes niso sestavljena samo iz poznavanja stroke, ki jo učitelji poučujejo, ampak v enaki meri tudi iz psihološko-pedagoških znanj in veščin, ki jih morajo bodoči učitelji prav tako pridobiti že v času študija (Peklaj, Puklek Levpušček $2006,42)$. Ob vsem tem ostaja neizpodbitno dejstvo, da je kvalitetno strokovno znanje ključna 
podlaga, iz katere izhaja dober učitelj, vendar je brez ustreznega razpolaganja s psihološkopedagoškimi znanji in veščinami v razredu dobesedno »bos«. Specialni didaktiki naj bi v prvi vrsti težili k usposabljanju študentov v smeri smiselnega horizontalnega in vertikalnega povezovanja vseh zgoraj naštetih znanj, osmišljanju njihovega pomena in obenem njihovem praktičnem udejanjanju. Danes smo, vsaj upati je tako, že zelo daleč od tega, da bi kot učitelji odprli učni načrt, preleteli cilje ter nova pojma in gesla, nato pa brez ustrezne psihološkodidaktične nadgradnje vstopili v razred.

Geografski kurikulum je učitelju vodilo, kažipot in usmerjevalec njegovega dela $\mathrm{v}$ razredu, vendar je sam po sebi, vse do trenutka, ko ga učitelj s svojim dojemanjem osmisli v interakciji z učenci, le »geografsko okostje«. Zato bi tudi težko trdili, da je kurikulum izhodišče formuliranju kompetenc učitelja, kar je jasno razvidno iz samega nabora kompetenc, ki sicer postavljajo na prvo mesto kvalitetno strokovno znanje, nakar v nadaljevanju v veliki meri gradijo predvsem na psihološko-didaktičnih znanjih.

Vendar pa je kurikulum za delo učitelja nedvomno izredno pomemben, saj »predpisuje« tako učne cilje, nabor pojmov in gesel, predlaga možnosti medpredmetnih korelacij itd., kar je učitelju osnova za njegovo nadaljnje delo. Če kurikulum ni domišljen, če dopušča strokovne napake, labsuse, pomanjkljivosti, če je enoznačen in ne odpira novih možnosti, potem že v samem izhodišču močno oteži delo učitelju. Predvsem je takšna situacija težka za začetnika, kajti predvidevamo lahko, da bo praktik z dolgoletnimi bogatimi izkušnjami tovrstne probleme in zapreke znal reševati veliko bolj suvereno, odločno in uspešno. Z večanjem zahtev in pričakovanj, zapisanih v kurikulumu, opažamo tudi kvalitetne premike v načinih poučevanja, izboru učnih metod in strategij dela med učitelji geografije.

\section{SKLEP}

Zahteve sodobnega časa in prenovljene šole, različne izobraževalne poti, različno usposabljanje učiteljev za te zahteve ter dejstvo, da ob vstopu v učiteljski študij ni selekcijskih postopkov, ki bi že na začetku izbrali potencialne kandidate za tako zahtevne naloge, v določeni meri otežujejo delo izobraževalcev bodočih učiteljev. Kompetentnost učitelja je pogojena z sodelovanjem oz. delovanjem »skupaj z drugimi«, z izobraževanjem učiteljev, ki mora v seznamih kompetenc videti svoje cilje, ter profesionalnim razvojem učiteljev. Stroke morajo stremeti k takim ciljem programov za izobraževanje učiteljev, ki bodo že v osnovi vključevali možnosti za doseganje čim večjega števila želenih in potrebnih kompetenc. Potrebno je zagotoviti, da bodo študenti z vseh predmetnih področij vstopali v učiteljski poklic s potrebnimi znanji in veščinami, vrednotami in kompetencami, ki bodo imeli podlago v njihovi obstoječi akademski izkušnji na tak način, da bodo lahko to znanje (strokovnost) usmerili v poučevanje in učenje v šoli. Če želimo zadostiti profesionalnim in individualnim potrebam študentov in uveljavili te lastnosti v njihovi profesionalni praksi in nadaljnjem profesionalnem razvoju, je potrebno spodbujati aktivne in participativne učne stile študentov in jih aktivno vključevati v aktivne oblike usposabljanja in izobraževanja. Ob tem je potrebno imeti ves čas v mislih tri glavne skupine kompetenc dobrega praktika: transverzalne kompetence (generične spretnosti), osebne kompetence ter socialne ali medosebne kompetence. 
Z vidika izobraževanja bodočih učiteljev so pred geografijo, tako kot pred drugimi strokami, ki želijo imeti kvalitetne in visoko usposobljene kadre na področju izobraževanja, še zahtevne naloge, ki pa jih vsekakor ni nemogoče izpolniti. Vendar je to možno le ob ustreznem medsebojnem horizontalnem in vertikalnem povezovanju in sodelovanju vseh izobraževalnih institucij in teles, odgovornih za prihodnost učiteljskega poklica in kvalitetno delo učiteljev.

Pri tem nikakor ne moremo mimo simbiotičnega odnosa med kurikulumom in kompetencami učitelja. V raziskavi, ki je bila izvedena v sklopu projekta R.A.V.E. Space (Resnik Planinc 2006, 16), se je potrdila naša hipoteza, da učitelji, kljub zavedanju potrebe po spremembi (bodisi glede učnih vsebin bodisi glede strategij, metod, oblik itd.), sami od sebe le te redko udejanjijo. Večinoma čakajo na »višjo avtoriteto«, v našem primeru kurikulum oz. učni načrt, ki jim spremembo narekuje in jo je učitelj tudi dolžan izvesti. Dejstvo je, da so nabori kompetenc sami po sebi »mrtvi zapisi«, ki v določeni meri lahko vplivajo na zavest posameznika, kar pa nikakor ne pomeni, da se bo le to odrazilo v kakršnihkoli spremembah njegovega dela. Zato je nujno potrebno, da so kurikulumi večplastno prepleteni z želenimi kompetencami učitelja oziroma, drugače rečeno, da je njihova simbioza jasno razvidna in transparentna. Zato je ravno na področju izobraževanja usklajeno (so)delovanje med teoretiki in praktiki, med sestavljavci kurikulumov in njihovimi izvajalci ter med tistimi, ki definirajo kompetence in tistimi, katerim so namenjene, ključnega pomena.

\section{Viri in literatura}

Chalmers, L. 2007: The Geographies of Places, Spaces and Their Representation in School Curricula. Changing Geographies:Innovative Curricula (ed. Catling, S., Taylor, L.). International Geographical Union, Commission for Geographical Education, IGU CGE/ Herodot London Conference 2007.

Cvetek, S. 2004: Kompetence v poučevanju in izobraževanju učiteljev. Sodobna pedagogika, 55 (121), Zveza društev pedagoških delavcev Slovenije, Ljubljana.

Gold, J. R., Jenkins, A., Lee, R., Monk, J., Riley, J., Shepherd, I., Unwin, D. (1991), Teaching Geography in Higher Education. A Manual of Good Practice, The Institute of British Geographers, London.

Graves, N. 1996: Curriculum Development in Gepgraphy: an Ongoing Process. Geography in Education. Viewpoints on Teaching and Learning (ed. Kent, A., Lambert, D., Naish, M., Slater, F.)., Cambridge.

Key competiences. A developing concept in general compulsory education. Brussels: Eurydice, 2002. URL: http://www.mszs.si/eurydice/pub./eurydice/survey_5_en.pdf (citirano 25. 6. 2006).

Kosevski Puljić, B. 2006: Povezovanje teorije in prakse kot eden ključnih problemov v začetnem izobraževanju učiteljev nemščine. Teorija in praksa v izobraževanju učiteljev (ed. Peklja, C.) Univerza v Ljubljani, Filozofska fakulteta, Ljubljana.

Lidstone, J., 1996: Professionalism in Geographical Education, in Gerber, R., Lidstone, J. (ed.), Developments and Directions in Geographical Education.

Medmrežje 1: http://www.oecd.org/dataoecd/47/61/35070367.pdf (citirano 17. 1. 2007)

Peklaj, C., Puklek Levpušček, M., 2006: Pridobljene in želene kompetence diplomantov in 
študentov Filozofske fakultete. Teorija in praksa v izobraževanju učiteljev (ed. Peklja, C.) Univerza v Ljubljani, Filozofska fakulteta, Ljubljana.

Popit, S., 2001: Comparison of Geography Curriculum and Geography rextbooks in Middle, South Eastern and Eastern European Countries, in Resnik Planinc, T., Vovk Korže, A., (ed.), International Conference on European Dimension of Teaching Geography in Middle, South Eastern and Eastern European Countries in transition, Department of Geography, Faculty of Arts, University of Ljubljana, Ljubljana.

Razdevšek Pučko, C. 2004: Kakšnega učitelja potrebuje (pričakuje) današnja (in jutrišnja) šola? Sodobna pedagogika, 55 (121), Zveza društev pedagoških delavcev Slovenije, Ljubljana.

Resnik Planinc, T., Kosten Zabret, S. 2006: Kompetence učitelja geografije z vidika bodočih učiteljev geografije. Teorija in praksa v izobraževanju učiteljev (ed. Peklja, C.) Univerza v Ljubljani, Filozofska fakulteta, Ljubljana.

Resnik Planinc, T. 2006: Vrednote prostora kot integralni del izobraževanja. Geografski vestnik 78 - 2. Zveza geografskih društev Slovenije, Ljubljana.

Slovar slovenskega knjižnega jezika. Druga knjiga I - Na, 1985: Slovenska aka-demija znanosti in umetnosti, Inštitut za slovenski jezik, Ljubljana

\section{INFLUENCE OF THE GEOGRAPHICAL CURRICULUM ON COMPETENCES OF GEOGRAPHY TEACHERS}

\section{Summary}

Education should be regarded as a development, as suggested by Kelly (1990), in which the individuals foster their abilities, capabilities and understanding. The curriculum should thus enable and encourage students to recognise, explore, evaluate and, where appropriate, challenge all views of culture and all value systems (Resnik Planinc, 2005). Therefore developing important concepts of geography in education requires considerable cooperation among subject experts, researchers and authors from different countries. Only then will the result be a flexible and adaptable system that successfully introduces changes into curriculum, and provides appropriate education of future geography teachers (Popit, 2001).

Apart from pure geographical contents, a geography teacher should also study sociological, psychological, political and cultural aspects of learning and teaching geography. A professionally oriented course should effectively link theory and practice and make the beginning of a career easier. The nature, purposes and contexts of geographical education, with the emphasis on issues of lifelong learning, international comparative education and work-based learning, are of great importance. They are relevant to the fast changing world of new opportunities and learning throughout life and careers.

To meet all the requirements in Slovenia, as well as in many other European countries, innovation in geography curricula is necessary and inevitable. But the question remains: which path is the best, which path should we follow? Geography educators should focus on defining of knowledge and skills which will be needed to meet the requirements of modern society. In Slovenia many geography teachers perceive the specification of geographical content as the 
biggest educational problem. The methods of delivering that content receive far less attention.

In theory, a teacher should act as an observer, helping the students to consider different possibilities, set and follow their own schedules, and address their needs. Encouragement, accomplishing manageable tasks and recognition of achievements are important for students' self-esteem and further for their learning success. It is also clear that life-relevant competences cannot be developed by initial education alone. (Internet 1)

At the Department of Geography, Faculty of Arts, University of Ljubljana we did a research among the future geography teachers and experienced geography teachers. We wanted to establish if students and teachers were aware of the importance of teacher's key competences and discover their opinion about them. According to the results the 4th grade students and the experienced teachers know all about the competences and are perfectly aware of their importance. They were asked to evaluate different groups of competences in two ways. Firstly, they evaluated the importance of each competence and, secondly, their own achievement of each competence. The results would be of great help in preparing the future academic programme of didactic of geography. The paper presents only main conclusions, derived from the research.

According to the results of the survey students as well as teachers achieved the highest level in the group of competences dealing with the subject (geography) and its contents. They both consider this group of competences the most important one. The second most important group is for both, students and teachers, work in the classroom (communication, methods, leading, evaluation of knowledge). This group is also put in the second place regarding the extent of its achievement during their study. Regarding the achievement and importance students put in the third place the group of competences dealing with teacher's professionalism, while teachers put it in the third place as the achieved category and in the fourth place regarding its importance. They consider the operation of school more important. Students achieved the least in the field of the operation of school and they also consider it the least important among all (Resnik Planinc, Kosten Zabret, 2006)

It needs to be mentioned that students are perfectly aware that very good geographical knowledge is the base for everything mentioned above, although nowadays this competence seems to be in a shadow in comparison with the other groups of competences. The survey results confirm the importance of thoughtfully prepared and organized process of permanent cooperation between geography educators at all levels. The academic study should be matched to the needs of intending teachers, offering a stimulating programme of academic study and practical, professional experience. Students should have an opportunity to develop their own knowledge, skills and confidence needed for employment in geographical education-related occupations.

Higher education disciplines should establish high quality programmes of study which would enable achievement of the above mentioned competences. At the same time school curricula should bemodernized, thoughtfully structured, purified and interdisciplinary connected. The process should be focused on complex and symbiotic relation between curriculum and competences of geography teacher and their importance for geographical education. The competences should therefore be derived from the theories, concerning values, knowledge, curriculum and whole educational process, which underpin good pedagogical practice. 